\title{
Effects of Magnesium sulfate and Bupropion on Morphine Induced tolerance in mice
}

Bohlool Habibi-asl ${ }^{1}$, Saeed Ghanbarzadeh ${ }^{2,3}$, Haleh Vaez ${ }^{1,2^{*}}$, Mina Khodabandeh ${ }^{2}$

1. Department of Pharmacology, Faculty of Pharmacy, Tabriz University of Medical Sciences, Tabriz, Iran

2. Student research Committee, Faculty of Pharmacy, Tabriz University of Medical Sciences, Tabriz, Iran

3. Department of Pharmaceutics, Faculty of Pharmacy, Tabriz University of Medical Sciences, Tabriz, Iran

\begin{abstract}
Introduction: Chronic opiate exposure induces tolerance to opiate analgesic effects. Glutamate system is believed to play a major role in morphine induced tolerance. The inhibitory effects of magnesium sulfate and bupropion on this system are well-studied. The aim of this study was to evaluate the effects of magnesium sulfate and bupropion on the prevention of morphine induced tolerance in mice.

Materials and Methods: Animals were divided into the nine groups which received drugs intraperitoneally for four consecutive days according to the following protocol: saline $(10 \mathrm{ml} / \mathrm{kg})+$ saline $(10 \mathrm{ml} / \mathrm{kg})$, morphine $(50 \mathrm{mg} / \mathrm{kg})+$ saline $(10 \mathrm{ml} / \mathrm{kg})$, morphine $(50 \mathrm{mg} / \mathrm{kg})+$ magnesium sulfate $(20,40$ and $60 \mathrm{mg} / \mathrm{kg})$, morphine $(50 \mathrm{mg} / \mathrm{kg})+$ bupropion $(2,4$ and $8 \mathrm{mg} / \mathrm{kg})$ and morphine $(50 \mathrm{mg} / \mathrm{kg})+$ magnesium sulfate $(20 \mathrm{mg} / \mathrm{kg})+$ bupropion $(2 \mathrm{mg} / \mathrm{kg})$. To evaluate the effects of mentioned drugs on morphine tolerance, a test dose of morphine $(9 \mathrm{mg} / \mathrm{kg})$ was administered on the fifth day in all groups. In the hot-plate test, thermal stimulation was measured at time intervals of $0,15,30,45$ and 60 minutes.

Results: Administration of magnesium sulfate, bupropion and their combination before daily injection of morphine, significantly attenuated tolerance to morphine. Also, the highest tolerance reduction was observed at the 30th minute of the study $(P<0.001)$.

Conclusion: Magnesium sulfate and bupropion can be used to attenuate morphine induced tolerance. The possible mechanisms are antagonist behavior on N-methyl-D-aspartate (NMDA) receptor and inhibition of glutamate release, respectively.
\end{abstract}

Key words: Bupropion; Hot plate; Magnesium sulfate; Morphine; Tolerance

\section{Introduction}

Opiate analgesics are broadly used throughout the management of pain. However,

repeated and long term administration of opiates could be associated with tolerance to opiates restricting their administration (1).

\section{Corresponding author:}

Haleh Vaez

Department of Pharmacology, Faculty of Pharmacy, Tabriz University of Medical Sciences, Tabriz, Iran Tel: (+98)411-3372250 Fax: (+98)411-3344798 Emails: vaezh@tbzmed.ac.ir; haleh.vaez@gmail.com

Receive date: 2014-08-25| Accept date: 2014-09-25| Publish date: 2014-10-05

DOI: 10.7575/aiac.abcmed.15.03.02.05 
Tolerance, i.e. diminution of the drug efficacy following long-term administration, could be associated with the requirement of augmented analgesic doses in order to obtain anticipated effects (2). To maintain proper pharmacologic approaches for controlling chronic pain, management of the tolerance process seems inevitable. Chronic opioid treatment leads to activation of $\mathrm{N}$-methyl-D-aspartate (NMDA) receptor and subsequent release and influx of intracellular $\mathrm{Ca} 2+$ and activation of protein kinase $C$ (PKC) (3, 4). Consequently, administration of NMDA receptor antagonists (e.g. ketamine) is known to prolong and enhance the analgesic effects of morphine and prohibit analgesic tolerance (5-8). Magnesium is a NMDA channel blocker used in hypomagnesaemia, toxemia of pregnancy, torsade's de pointes dysrhythmias and preterm labor $(9,10)$. It can also diminish the tolerance and dependence to the analgesic effects of morphine through blocking $\mathrm{Ca} 2+$ channels related to NMDA receptors (11-14).

Bupropion, a non-tricyclic antidepressant, is a popular treatment in SSRI's intolerance, or for people wanting to quit smoking. In recent studies, potential use of bupropion in tolerance and dependence has been indicated (15). Magnesium sulfate and bupropion may have a potential role in the prevention of morphine tolerance. In the present study we investigated the effect of pretreatment of magnesium sulfate, bupropion and co-administration of them in the development of morphine induced tolerance.

\section{Materials and methods}

\section{Drugs}

Morphine sulfate was obtained from Darupakhsh Company (Iran). Magnesium sulfate from Pasteur institute (Iran) and bupropion were purchased from Abidi pharmaceutical company (Iran).
Seventy two adult male albino mice weighing 20-30 g (age: 8 weeks) were divided into nine groups $(n=8)$. Animals had free access to food and water and were maintained in room temperature $(24 \pm 0.5 \circ \mathrm{C})$ under standard lighting conditions (12h: 12h, light: darkness). All experiments were executed in accordance with the Guide for Care and Use of Laboratory Animals of Tabriz University of Medical Sciences, Tabriz, Iran. (National Institutes of Health Publication No 85-23, revised 1985). The study was conducted in Pharmacy faculty of Tabriz University of Medical Science.

Induction of tolerance and treatment protocols

Animals were divided into nine groups which received drugs intraperitoneally for four consecutive days according to the following protocol: Group 1: saline (10 ml/kg) + saline (10 $\mathrm{ml} / \mathrm{kg}$ ), Group 2: morphine (50 $\mathrm{mg} / \mathrm{kg})+$ saline (10 $\mathrm{ml} / \mathrm{kg})$, Group 3, 4 and 5: morphine (50 $\mathrm{mg} / \mathrm{kg})+$ magnesium sulfate $(20,40$ and 60 $\mathrm{mg} / \mathrm{kg}$ ), Group 6, 7 and 8: morphine $(50 \mathrm{mg} / \mathrm{kg}$ ) + bupropion (2, 4 and $8 \mathrm{mg} / \mathrm{kg}$ ) and Group 9: morphine $(50 \mathrm{mg} / \mathrm{kg})+$ magnesium sulfate (20 $\mathrm{mg} / \mathrm{kg})+$ bupropion $(2 \mathrm{mg} / \mathrm{kg})$. To evaluate the degree of tolerance in each group, a test dose of morphine $(9 \mathrm{mg} / \mathrm{kg}$ ) was administered 24 hours after the last dose of morphine. In the hot-plate test, thermal stimulation was measured at time intervals of $0,15,30,45$ and 60 minutes.

\section{Hot-plate test}

Hot plate is a widely used test to assess nociception. Each mice was placed on a surface $(23 \times 23 \mathrm{~cm})$ maintained at $52 \pm 0.50 \mathrm{C}$ surrounded by a plexiglass wall with $20 \mathrm{~cm}$ height. Hot-plate latency was recorded when the animal licked its hind paw. A cut-off time $(40 \mathrm{sec})$ was imposed to prevent tissue damage. Hot-plate response latency results were expressed as the percentage of Maximal

Animals 
Possible Effect (MPE \%) according to the Results following equation:

MPE \% = [(TL - BL) / (T cut-off - BL) $] \times 100$

$\mathrm{TL}$ and $\mathrm{BL}$ stand for Test Latency time and Base Latency time, respectively.

Statistical analysis

Statistical analysis of each data set was performed by SPSS software (version 17). All results were presented as mean \pm SEM for eight rats. Statistical comparisons among the experimental groups were made by one way analysis of variance (ANOVA) followed by Tukey post-hoc test where differences with $p$ values less that 0.05 were considered significant.
Development of morphine induced tolerance to analgesic effects

In both groups of saline and morphine, antinociceptive responses of a test dose of morphine $(9 \mathrm{mg} / \mathrm{kg}, \mathrm{IP})$ was assayed $24 \mathrm{~h}$ after the last dose of morphine $(50 \mathrm{mg} / \mathrm{kg}, \mathrm{IP})$ and saline injection in morphine and saline receiving groups, respectively. Animals that became tolerant to morphine exhibited only a small anti-nociceptive effect. Compared to saline group, morphine receiving group showed lesser MPE \% due to developed tolerance (Fig. 1).

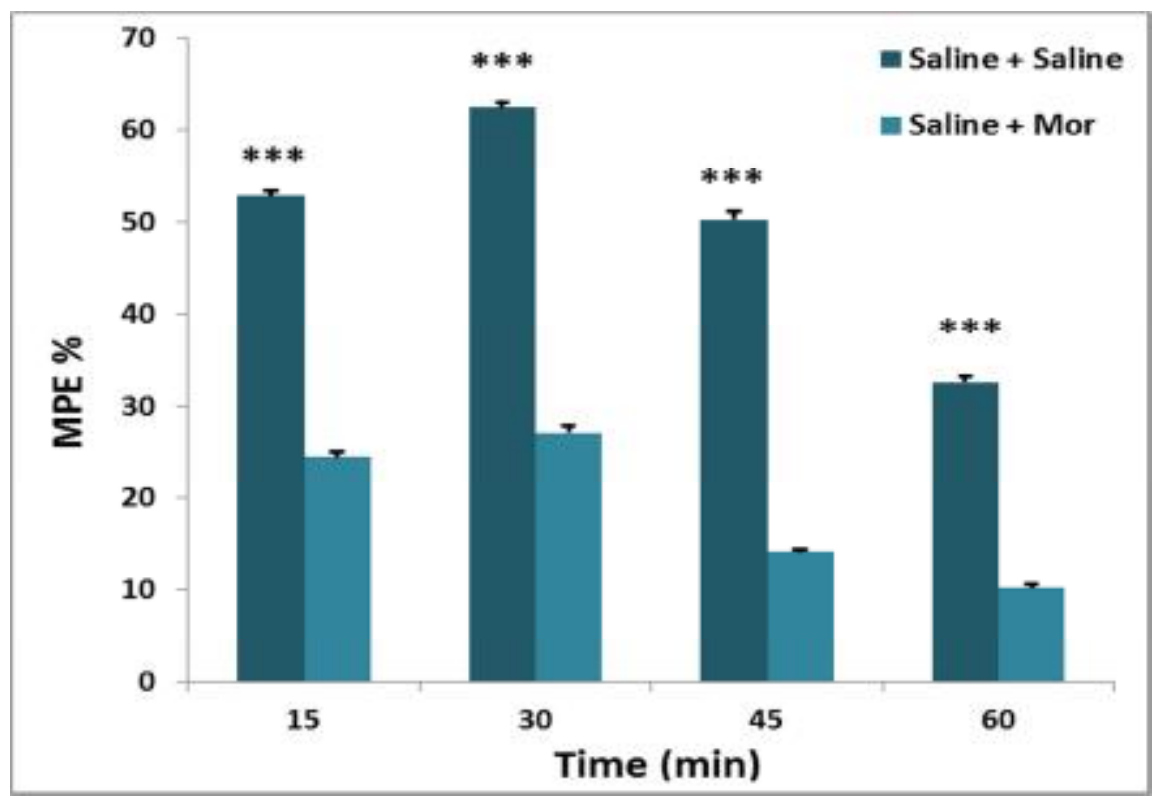

Figure 1: Effects of morphine on tolerant and non-tolerant mice. Saline group received saline (10 $\mathrm{ml} / \mathrm{kg}$, ip) + saline (10 ml/kg, ip) for 4 days and morphine receiving group treated by morphine (Mor, $50 \mathrm{mg} / \mathrm{kg}$, ip) + saline $(10 \mathrm{ml} / \mathrm{kg}$, ip) for 4 days. Results are expressed as Mean \pm SEM for eight rats in each group. ${ }^{* * *} \mathrm{P}<0.001$, significantly different from the control group (Saline + Saline).

Effects of administration of magnesium sulfate on morphine induced tolerance

As it is shown in Figure 2, magnesium sulfate injection $(20,40$ and $60 \mathrm{mg} / \mathrm{kg}, \mathrm{IP}) 30 \mathrm{~min}$ analgesic effects of morphine in a dose dependently manner. The best result was achieved in dose of $60 \mathrm{mg} / \mathrm{kg}$ of magnesium sulfate which was more significant at the time before daily morphine administration, decreased significantly the tolerance to the of 30 and $45 \mathrm{~min}$. 


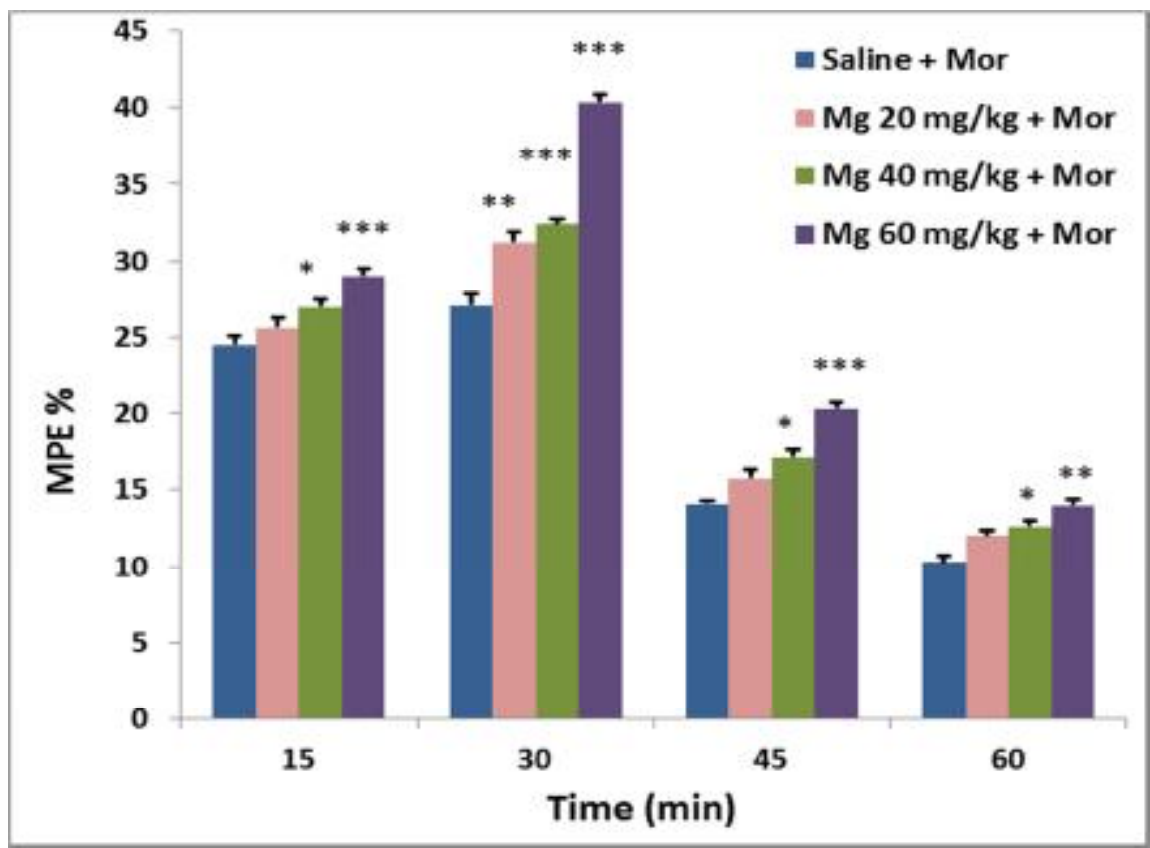

Figure 2: Effects of different doses of magnesium sulfate ( $\mathrm{Mg} ; 20,40$ and $60 \mathrm{mg} / \mathrm{kg}$, ip) on morphine induced tolerance. Results are expressed as Mean \pm SEM for eight rats in each group. ${ }^{*} \mathrm{P}<0.05,{ }^{* *} \mathrm{P}<0.01$ and ${ }^{* * *} \mathrm{P}<0.001$, significantly different from the control group (Saline + Mor).

Effects of administration of bupropion on morphine induced tolerance Administration of bupropion reduced the tolerance to the morphine (Fig. 3) and the maximum preventative effect on tolerance was observed at the time 30 and $45 \mathrm{~min}$. Similar to magnesium, the higher dose of bupropion (8 $\mathrm{mg} / \mathrm{kg}$ ) was found to be the best dose for morphine induced tolerance prevention.

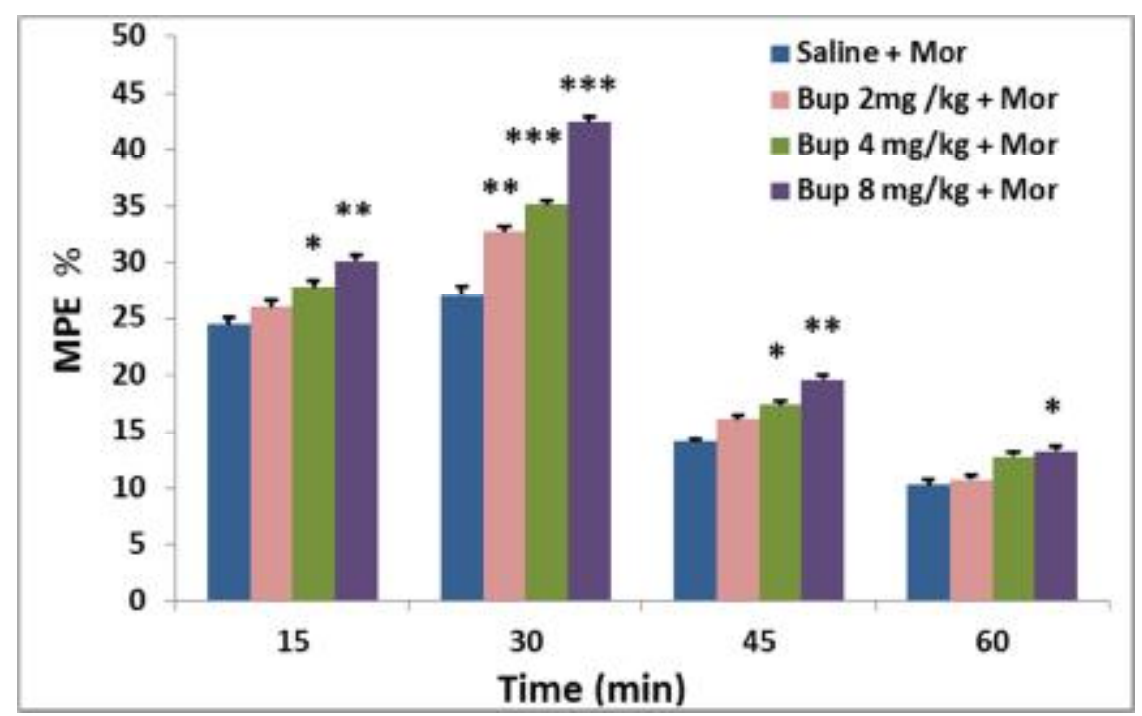

Figure 3: Effects of different doses of bupropion (Bup; 2,4 and $8 \mathrm{mg} / \mathrm{kg}$, ip) on morphine induced tolerance. Results are expressed as Mean \pm SEM for eight rats in each group. ${ }^{*} \mathrm{P}<0.05,{ }^{* *} \mathrm{P}<0.01$ and $* * * \mathrm{P}<0.001$, significantly different from the control group (Saline + Mor). 
Effects of co-administration of magnesium sulfate and bupropion on morphine induced tolerance

Fig. 4 illustrates the preventative effects of coadministration of magnesium sulfate $(20$ $\mathrm{mg} / \mathrm{kg}, \mathrm{IP}$ ) and bupropion (2 $\mathrm{mg} / \mathrm{kg}, \mathrm{IP}$ ) on morphine induced tolerance. As shown, the combination therapy had synergic effects on the prevention of morphine induced tolerance and this difference in tolerance level was higher compared to the both of the single injection of drugs in all time intervals. In other words, the combination of low dose of each drug exhibited more effective results in comparison even with the high dose of each drug in single administration.

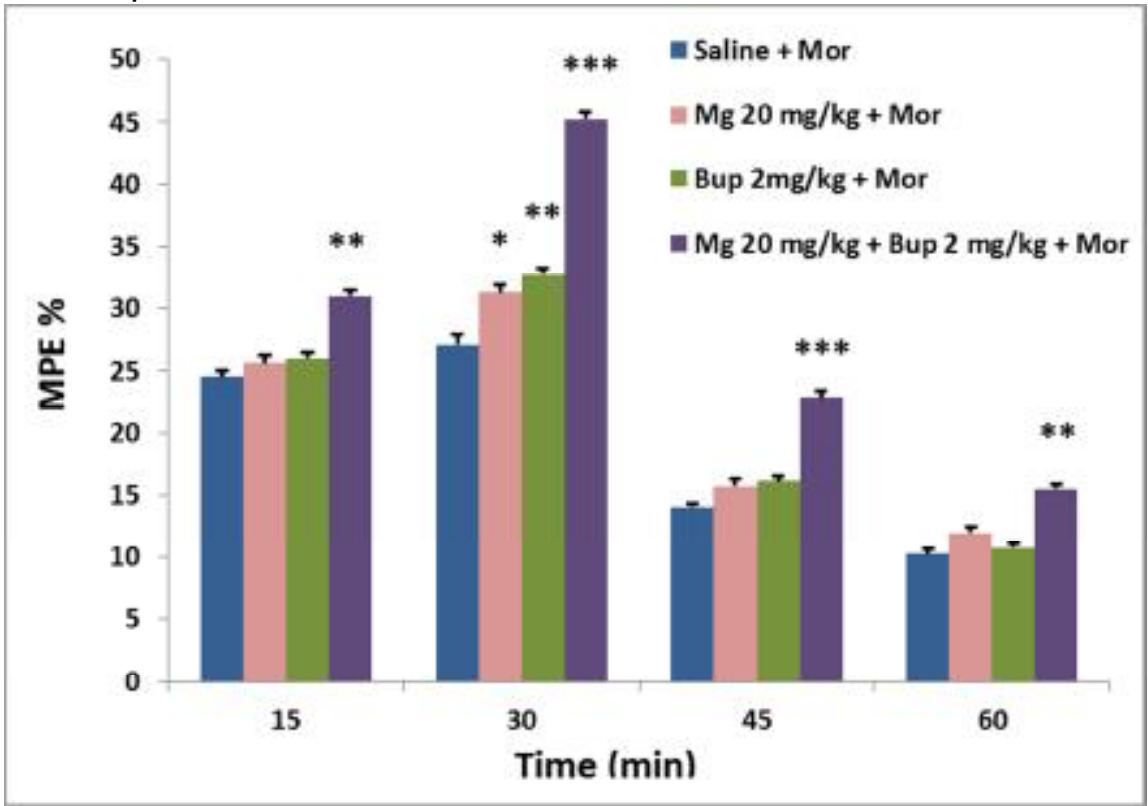

Figure 4: Effects of co-administration of magnesium sulfate $(\mathrm{Mg}, 20 \mathrm{mg} / \mathrm{kg}$, ip) and bupropion (Bup, $2 \mathrm{mg} / \mathrm{kg}$, ip) on morphine induced tolerance. Results are expressed as Mean \pm SEM for eight rats in each group. ${ }^{*} P<0.05,{ }^{* *} P<0.01$ and ${ }^{* * *} P<0.001$, significantly different from the control group (Saline + Mor).

\section{Discussion}

Opioid tolerance is a complex event mediated by diverse behavioral and cellular adaptations. Recent studies propose that repeated administration of opiate enhance activation of NMDA-receptors through $\mathrm{G}$ protein associated opioid receptors $(16,17)$. The responsible mechanism is through opioid-mediated PKC activation which removes magnesium blockade of NMDA receptors and the final effect is NMDA receptors activation. Following NMDA activation as a positive feedback, additional PKC translocation and activation is stimulated which eventually result in hyperalgesia and opioid tolerance (18-21). This opiate related activation of NMDA-receptors initiates intracellular changes such as influx of $\mathrm{Ca} 2+$ and subsequent production of nitric oxide (NO) and increase in cGMP level, which all have been shown to contribute critically to the opioid tolerance development $(22,23)$. NO is able to further increase excitotoxicity by enhancing glutamate release from presynaptic neurons and inhibiting glial glutamate transporters (2429). Although the exact mechanism of tolerance development is not well-understood, some mechanisms such as norepinephrine dopamine reuptake inhibition and also glutamate release inhibition have been reported to play role (30). 
Glutamatergic activation of NMDA receptors is involved in morphine tolerance, and the blockade of this system by different NMDA receptor antagonists, such as MK-801 and ketamine has been reported (31-36). Based on these evidences and according to the results of this study, the efficacy of bupropion and magnesium sulfate in reducing morphine induced tolerance is demonstrated.

Investigations by Lin et al. resulted in a dosedependent inhibition of 4-aminopyridine (4AP)-evoked release of glutamate by suppressing voltage-dependent $\mathrm{Ca} 2+$ channel and MEK/ERK activity of bupropion (37-40). Therefore, through this inhibitory effect of bupropion on glutamate level, the affection on NMDA receptors is mediated and it can be considered as the responsible mechanism of effectiveness of bupropion on tolerance process. In addition, the property of dopamine and norepinephrine reuptake inhibitory of bupropion may have a role in preventing tolerance phenomena emergence.

That NMDA receptors are generally blocked by magnesium at the resting membrane potentials is well-known. Chronic administration of opiate could be associated with antagonization of magnesium blockade of NMDA receptors followed by opening of the $\mathrm{Ca} 2+$ channels and increase in intracellular $\mathrm{Ca} 2+$ concentrations (41-43). Interestingly, this could be reversed by administration of magnesium; the mechanism behind this phenomenon is the potency of magnesium in blocking the Ca2+ channel of NMDA receptors (44). This, however, is not limited to the above-mentioned mechanism and the following mechanisms have also been identified: decreasing presynaptic release of catecholamines especially dopamine, glutamate effect on NMDA receptors in the brain and direct action of $\mathrm{Mg} 2+$ on serotonin receptors (45-47).

Considering all these roles of magnesium sulfate and bupropion and the neurobiology of tolerance phenomena, the basis of coadministration of these drugs can be explained and supported by the results obtained from this study. Furthermore, combination of magnesium and bupropion is of further effective analgesic properties than either compound alone. This might be imputed to different and multiple effects of these drugs in tolerance inducing pathway which result in acting in a super-additive manner.

\section{Conclusion}

Low doses of bupropion $(2 \mathrm{mg} / \mathrm{kg}, \mathrm{IP})$ in combination with a low dose of magnesium (20 $\mathrm{mg} / \mathrm{kg}$, IP) decreases the development of morphine tolerance. Increased efficacy of morphine, especially in the treatment for chronic pain, could be achieved through pharmacological manipulation of NMDA receptor activity.

\section{Acknowledgments}

We wish to thank the authorities of Faculty of Pharmacy, Tabriz University of Medical Sciences. This article is on the base of a Pharm. $D$ thesis (No. 3715) results, submitted in the Faculty of Pharmacy, Tabriz University of Medical Sciences, Tabriz, Iran.

\section{References}

1. Liu JG AK. Protein kinase modulate the cellular adaptation associated with opioid tolerance and dependence. Brain Res Rev. 2001;38:1-19.

2. Mayer D.J MJ. mechanisms of opioid tolerance current view of cellular mechanisms. Pain Forum. 1999;8:14-8.

3. Kramer HK, Simon EJ. Role of protein kinase C (PKC) in agonist-induced mu-opioid receptor down-regulation: II. Activation and involvement of the alpha, epsilon, and zeta isoforms of PKC. Journal of neurochemistry. 1999 Feb;72(2):594-604. 
4. Fundytus ME, Coderre TJ. Chronic inhibition of intracellular Ca2+ release or protein kinase $\mathrm{C}$ activation significantly reduces the development of morphine dependence. European journal of pharmacology. 1996 Apr 11;300(3):173-81.

5. Kaymak C YE, Basar H, Ozcakir S, Apan A, Batislam E. Use of the NMDA antagonist magnesium sulfate during monitored anesthesia care for shockwave lithotripsy. J Endourol. 2007;21:145-50.

6. Mendes IA TK. NMDA reseptor antagonists inhibit opiate antinociceptive tolerance and locomotor sensitization in rats. Psychopharmacology. 2008;196:497-509.

7. Kozela E, Popik P. The effects of NMDA receptor antagonists on acute morphine antinociception in mice. Amino acids. 2002;23(1-3):163-8. doi: 10.1007/s00726-001-0123-5.

8. Bisaga A, Popik P. In search of a new pharmacological treatment for drug and alcohol addiction: N-methyl-Daspartate (NMDA) antagonists. Drug and alcohol dependence. 2000 Apr 1;59(1):1-15.

9. Smetana R SH, Kiss K, Glogar DH. Intravenous magnesium sulphate in acute myocardial infarction. Magnes Res. 2003;16:65-9.

10. Wiswell TE GL, Caddell JL, Vecchione N, Stanley C, Spitzer AR. The possible role of magnesium in protection of premature infants from neurological syndromes and visual impairments and a review of survival of magnesiumexposed premature infants. Magnes Res. 1999:201-16.

11. Trescot AM DS, Lee M, Hansen H Opioid pharmacology. Pain Physician. 2008;11:133-53.

12. McCarthy RJ, Kroin JS, Tuman KJ, Penn RD, Ivankovich AD. Antinociceptive potentiation and attenuation of tolerance by intrathecal co-infusion of magnesium sulfate and morphine in rats. Anesthesia and analgesia. 1998 Apr;86(4):830-6.

13. Habibi-Asl B, Hassanzadeh K, Vafai H, Mohammadi S. Development of morphine induced tolerance and withdrawal symptoms is attenuated by lamotrigine and magnesium sulfate in mice. Pakistan journal of biological sciences: PJBS. 2009 May 15;12(10):798-803.

14. KA T. Are NMDA receptors involved in opiate-induced neural and behavioral plasticity? A review of preclinical studies. Psychopharmacology. 2000;151:121-41.

15. Joshi D, Singh A, Naidu PS, Kulkarni SK. Protective effect of bupropion on morphine tolerance and dependence in mice. Methods and findings in experimental and clinical pharmacology. 2004 Oct;26(8):623-6.

16. Vanderah TW, Suenaga NM, Ossipov MH, Malan TP, Jr., Lai J, Porreca F. Tonic descending facilitation from the rostral ventromedial medulla mediates opioid-induced abnormal pain and antinociceptive tolerance. The Journal of neuroscience : the official journal of the Society for Neuroscience. 2001 Jan 1;21(1):279-86.

17. Prommer EE. Opioid-induced pain. Journal of clinical oncology : official journal of the American Society of Clinical Oncology. 2008 Jul 10;26(20):3464-5; author reply 5. doi: 10.1200/JCO.2008.17.3633.

18. Chen L, Huang LY. Protein kinase C reduces Mg2+ block of NMDA-receptor channels as a mechanism of modulation. Nature. 1992 Apr 9;356(6369):521-3. doi: 10.1038/356521a0.

19. Granados-Soto V, Kalcheva I, Hua X, Newton A, Yaksh TL. Spinal PKC activity and expression: role in tolerance produced by continuous spinal morphine infusion. Pain. 2000 Apr;85(3):395-404.

20. Li Y, Roerig SC. Alteration of spinal protein kinase $C$ expression and kinetics in morphine, but not clonidine, tolerance. Biochemical pharmacology. 1999 Aug 1;58(3):493-501.

21. Fan GH, Zhao J, Wu YL, Lou LG, Zhang Z, Jing Q, et al. N-Methyl-D-aspartate attenuates opioid receptor-mediated G protein activation and this process involves protein kinase C. Molecular pharmacology. 1998 Apr;53(4):684-90.

22. Zhao M, Joo DT. Subpopulation of dorsal horn neurons displays enhanced N-methyl-D-aspartate receptor function after chronic morphine exposure. Anesthesiology. 2006 Apr;104(4):815-25.

23. Trujillo KA. The neurobiology of opiate tolerance, dependence and sensitization: mechanisms of NMDA receptordependent synaptic plasticity. Neurotoxicity research. 2002 Jun;4(4):373-91. doi: 10.1080/10298420290023954. 
24. Adam F, Bonnet F, Le Bars D. Tolerance to morphine analgesia: Evidence for stimulus intensity as a key factor and complete reversal by a glycine site-specific NMDA antagonist. Neuropharmacology. 2006;51(2):191-202. doi: http://dx.doi.org/10.1016/j.neuropharm.2006.03.018.

25. Fischer BD, Ward SJ, Henry FE, Dykstra LA. Attenuation of morphine antinociceptive tolerance by a CB1 receptor agonist and an NMDA receptor antagonist: Interactive effects. Neuropharmacology. 2010;58(2):544-50. doi: http://dx.doi.org/10.1016/j.neuropharm.2009.08.005.

26. Ghasemi M, Shafaroodi H, Nazarbeiki S, Meskar H, Ghasemi A, Bahremand A, et al. Inhibition of NMDA receptor/NO signaling blocked tolerance to the anticonvulsant effect of morphine on pentylenetetrazole-induced seizures in mice. Epilepsy Research. 2010;91(1):39-48. doi: http://dx.doi.org/10.1016/j.eplepsyres.2010.06.010.

27. Guo R-x, Zhang M, Liu W, Zhao C-m, Cui Y, Wang C-h, et al. NMDA receptors are involved in upstream of the spinal JNK activation in morphine antinociceptive tolerance. Neuroscience Letters. 2009;467(2):95-9. doi: http://dx.doi.org/10.1016/j.neulet.2009.10.013.

28. Wen ZH, Wu GJ, Chang YC, Wang JJ, Wong CS. Dexamethasone modulates the development of morphine tolerance and expression of glutamate transporters in rats. Neuroscience. 2005;133(3):807-17. doi: http://dx.doi.org/10.1016/j.neuroscience.2005.03.015.

29. Zhou Q, Wang J, Zhang X, Zeng L, Wang L, Jiang W. Effect of metabotropic glutamate 5 receptor antagonists on morphine efficacy and tolerance in rats with neuropathic pain. European journal of pharmacology. 2013;718(1-3):1723. doi: http://dx.doi.org/10.1016/j.ejphar.2013.09.009.

30. Lin TY, Yang TT, Lu CW, Wang SJ. Inhibition of glutamate release by bupropion in rat cerebral cortex nerve terminals. Progress in neuro-psychopharmacology \& biological psychiatry. 2011 Mar 30;35(2):598-606. doi: 10.1016/j.pnpbp.2010.12.029.

31. Trujillo KA, Akil H. Inhibition of morphine tolerance and dependence by the NMDA receptor antagonist MK-801. Science. 1991 Jan 4;251(4989):85-7.

32. Gutstein HB, Trujillo KA. MK-801 inhibits the development of morphine tolerance at spinal sites. Brain research. 1993 Oct 29;626(1-2):332-4.

33. Allen RM, Dykstra LA. The competitive NMDA receptor antagonist LY235959 modulates the progression of morphine tolerance in rats. Psychopharmacology (Berl). 1999 Feb;142(2):209-14.

34. Habibi-Asl B, Hassanzadeh K, Khezri E, Mohammadi S. Evaluation the effects of dextromethorphan and midazolam on morphine induced tolerance and dependence in mice. Pakistan journal of biological sciences: PJBS. 2008 Jul 1;11(13):1690-5.

35. Habibi-Asl B, Hassanzadeh K, Moosazadeh S. Effects of ketamine and magnesium on morphine induced tolerance and dependence in mice. DARU. 2005;13:110-5.

36. Habibi-Asl B, Hassanzadeh K. Effects of ketamine and midazolam on morphine induced dependence and tolerance in mice. DARU. 2004;12:101-5.

37. Ferry LH BR. Efficacy of bupropion for smoking cessation in non-depressed smokers. J Addict Dis. 1994;13:249.

38. Gadde K M PCB, Maner L.G. Bupropion for weight loss: an investigation of efficacy and tolerability in overweight and obese women. Obes Res. 2001;9:544-51.

39. Learned-Coughlin SM BM, Savitcheva I, Ascher J, Schmith VD, Langstrom B. In vivo activity of bupropion at the human dopamine transporter. Biol Psychiatry 2003;54:800-5.

40. Lin TY YT, Lu CW, Wang SJ. Inhibition of glutamate release by bupropion in rat cerebral cortex nerve terminals. Prog Neuropsychopharmacol Biol Psychiatry. 2011;35:598-606.

41. Wollmuth LP, Kuner T, Sakmann B. Intracellular Mg2+ interacts with structural determinants of the narrow constriction contributed by the NR1-subunit in the NMDA receptor channel. The Journal of physiology. 1998 Jan 1;506 (Pt 1):33-52. 
42. Ruppersberg JP, Kitzing Ev, Schoepfer R. The mechanism of magnesium block of NMDA receptors. Seminars in Neuroscience. 1994 ;6(2):87-96. doi: http://dx.doi.org/10.1006/smns.1994.1012.

43. Martin G, Ahmed SH, Blank T, Spiess J, Koob GF, Siggins GR. Chronic morphine treatment alters NMDA receptormediated synaptic transmission in the nucleus accumbens. The Journal of neuroscience : the official journal of the Society for Neuroscience. 1999 Oct 15;19(20):9081-9.

44. Begon S, Pickering G, Eschalier A, Dubray C. Magnesium increases morphine analgesic effect in different experimental models of pain. Anesthesiology. 2002 Mar;96(3):627-32.

45. Kalipatnapu S, Jafurulla M, Chandrasekaran N, Chattopadhyay A. Effect of Mg2+ on guanine nucleotide sensitivity of ligand binding to serotonin1A receptors from bovine hippocampus. Biochemical and biophysical research communications. 2004 Oct 15;323(2):372-6. doi: 10.1016/j.bbrc.2004.08.120.

46. Papierkowski A, Pasternak K. The effect of a single dose of morphine and ethanol on magnesium level in blood serum and tissues in mice. Magnes Res. 1998 Jun;11(2):85-9.

47. Nechifor M, Chelarescu D, Miftode M. Magnesium influence on morphine--induced pharmacodependence in rats. Magnes Res. 2004 Mar;17(1):7-13. 